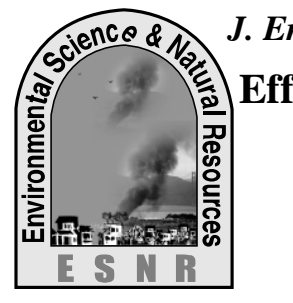

Environ. Sci. \& Natural Resources, 6(2): 37- 41, 2013

ISSN 1999-7361

\title{
Effects of Flooding on Socio-Economic Status of Two Integrated Char Lands
} of Jamuna River, Bangladesh

\author{
M. N. Hossain ${ }^{1}$, M. N. Uddin' ${ }^{2}$ M. Rokanuzzaman ${ }^{3}$, M. A. Miah ${ }^{3}$ and M. Alauddin ${ }^{1}$ \\ ${ }^{1}$ Department of Environmental Science and Resource Management, \\ Mawlana Bhashani Science and Technology University. \\ ${ }^{2}$ Institute of Water and Flood Management (IWFM), \\ Bangladesh University of Engineering and Technology (BUET), Dhaka-1000, \\ ${ }^{3}$ Department of Environmental Science, \\ Bangladesh Agricultural University Mymensingh-22O2, Bangladesh
}

\begin{abstract}
The study observed the effects of flooding on socio-economic status of two integrated char lands of Jamuna River in Bangladesh during the period from March 2011-September 2011. Data were collected on primary and secondary sources. The Primary data was collected from the field level through intrinsic study and secondary data were collected from various sources vz. Bangladesh Water Development Board, Statistical Bureau, Agricultural office, published journals etc. The questionnaire survey was conducted on the char land's people in order to reveal their perception regarding effects of flooding and management and adaptation strategies. The study revealed that floods have long-term negative implications on socio-economic status. According to survey followed by the most affected sector was agriculture $(53.33 \%)$, followed by health (17.77\%) and property (26.66\%), diseases as Diarrhea occurred at alarming levels (77.77\%). In the year 2011 the crop damage (57.77\%) and house damage wise significant $(26.66 \%)$ and roads communications were also highly affected by flood. The study obtained the difference-indifference estimates the magnitude of impact of flood on socio-economic status depending on the relative flood prone area and the severity of flooding and its associated impacts.
\end{abstract}

Key Word: Char land, Flood, Livelihood, Socioeconomic status

\section{Introduction}

Bangladesh is a disaster prone country; it is subject to colossal damages to life and property almost every year. Bangladesh is most vulnerable to several natural disasters and every year natural calamities upset people's lives in some part of the country. The major disasters concerned here are the occurrences of flood, cyclone and storm surge, flash flood, drought, tornado, riverbank erosion, and landslide. These extreme natural events are termed disasters when they adversely affect the whole environment, including human beings, their shelters, or the resources essential for their livelihoods (Bangladesh: State of the Environment, 2001).

Bangladesh is one of the least developed countries of the world with an area of 147570 square kilometers. The population is 160 million with growing rate of 1.34 percent per annum (UNDP, 2011) and more than 75 percent of the population lives in the rural areas Bangladesh is also a disaster prone country (Hossain et al., 2004). It is also a developing country discharge with numerous problems of over population, poverty complex socio economic structure, frequent disasters, low level industrial base, resource constraints and lack of appropriate infrastructural and institutional facilities. Major factors responsible for disaster $s$ in Bangladesh are flat topography, rapid run off and drainage congestion, low relief of the flood plains, low river gradients, heavy monsoon rainfall and enormous discharge of sediments, funnel shapes and shallow Bay of Bengal. These problems are complicated and compound with the occurrence of regular and frequent disasters impeding the overall socio-economic development efforts of the country. According to the satellite data the river consumes about 8,700 hectares of arable land every year (Khan et al., 1999).

Flooding is a natural phenomenon, which cannot be prevented. The flood control measures and policies should be directed to mitigation of flood damage, rather than flood prevention. Most of the people of Char land area are facing various problems such as sanitation and health, change of food habit; among them lose their permanent resident and become environmental refugees during flood. The result shows that, due to flood, most of the people lost their job and led to decrease income level. Normally the intensity of flood in July-August that time the severe problem are seen lack of food, damage crop, road infrastructure. Various diseases like waterborne such cholera, dysentery, fever, diarrhea and some other diseases occur.

Floods make an enormous impact on the environment and society. Floods destroy drainage systems in cities, causing raw sewage to spill out into bodies of water. This can lead to catastrophic effects on the environment as many toxic materials such as paint, pesticide and gasoline can be released into the rivers, lakes, bays, and ocean, killing maritime life. Floods may also cause millions of dollars worth of damage to a city, both evicting people from their homes and ruining businesses. Floods cause significant amounts 
of erosion to coasts, leading to more frequent flooding if not repaired. However, floods do make a slight positive impact on the environment. Floods spread sediment containing beneficial nutrients to topsoil (Wikipedia, 2009). Keep in the above views in mind the present work was undertake to evaluate the Effects of Flooding on Socio-Economic Status of Two Integrated Char Lands of Jamuna River, Bangladesh.

\section{Materials and Methods}

The study was conducted in the two integrated char land such as Afjalpur, and Jalbali, char under Durgapur Union of Khalihati Thana in Tangail District. Kalihati is located $90^{\circ} 20^{\prime}$ east to $89^{\circ} 40^{\prime}$ North latitude. According to the Bangladesh Census 2001 Khalihti has a total population of 29823; male $50.26 \%$, female $49.74 \%$. The literacy rate among the town people is $28.9 \%$. The density of population is 12478 per sq km. Population 354959; male 51.55\%, female 48.45\%; Muslim 90.02\%, Hindu 9.2\%, Buddhist $0.14 \%$, Christian $0.15 \%$, others $0.49 \%$. Average annual temperature: maximum $33.3^{\circ} \mathrm{C}$, minimum $12^{\circ} \mathrm{C}$; annual rainfall $1467 \mathrm{~mm}$. The location of Afjalpur, and Jalbali, chor under the Durgapur Union parishad of Kalihati Upazilla. The total land area of two char is 600 acres. The total population is 2000 most of them are day laborer and illiterate. The quality of the soil of study area is fertile but low land. Average annual temperature: maximum $33.3^{\circ} \mathrm{C}$, minimum $12^{\circ} \mathrm{C}$; annual rainfall $1467 \mathrm{~mm}$. The Data was collected based on primary and secondary sources. The Primary data was collected from the field level through intrinsic study during the period from March 2011-September 2011. The secondary data was collected from various sources vz. Bangladesh Water Development Board, Statistical Bureau, Agricultural office, published journal etc. The questionnaire survey was conducted on the char land's people in order to reveal their perception regarding effects of flooding and management and adaptation strategies.

\section{Results and Discussion}

\section{Causes of Flooding}

There are many causes which are responsible for flooding in Bangladesh. From the (Fig. 1) shows that, $71 \%$ respondent said the main cause of flooding is low land in the study area, which was the highest followed by the $27 \%$ respondent who said the Farraka Barrage is also responsible for flooding. The only $2 \%$ respondent said that, lack of proper management system was also responsible for flooding.

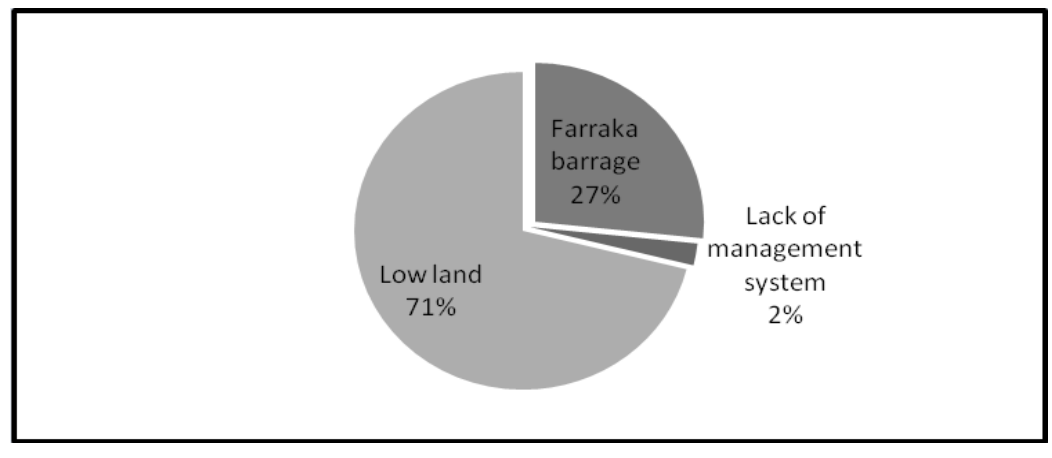

Fig. 1. Causes of Flooding

\section{Problem Faced during Flood}

Figure shows that during flood in Bangladesh the human being faces many problems. The study found that, the $60 \%$ of respondent said that the most common problem was the lack of food during flood.
The $33.33 \%$ of the respondents said that communication problem occurred during flood. The percentage of respondent was health service problem occurred during flood in the study area; the value was $6.66 \%$ (Fig. 2).

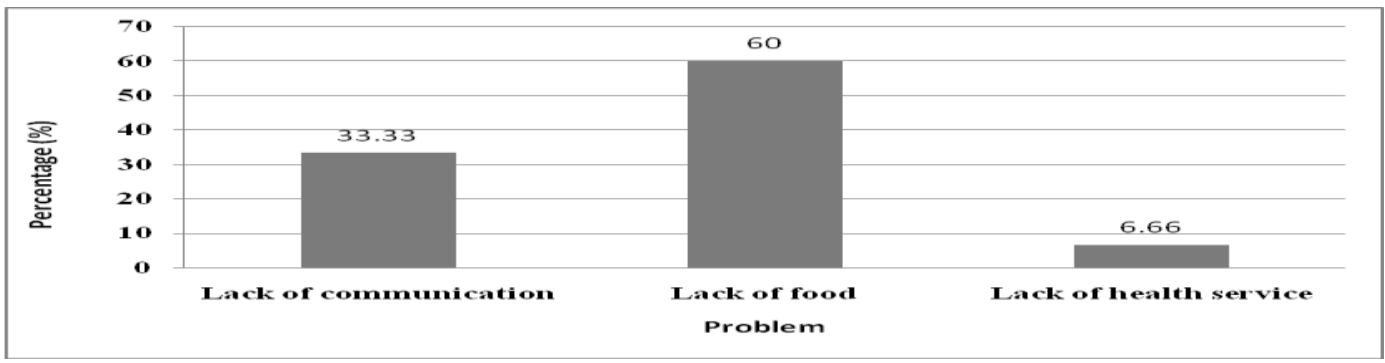

Fig. 2. Problem Faced during Flood 


\section{Sectors Affected by Flood}

Fig. 3. Shows that during flood, different sector have been damaged and loss of property happened. The study revealed that, $53.33 \%$ of respondent said that Agriculture was the most common sector which is affected by during flood, followed by the $26.66 \%$ respondents said the properties were affected during flood. A signicicant percentage of respondents said the health and live stock were also affected by the flood, the value were $17.77 \%$ and $2.22 \%$ respectively.

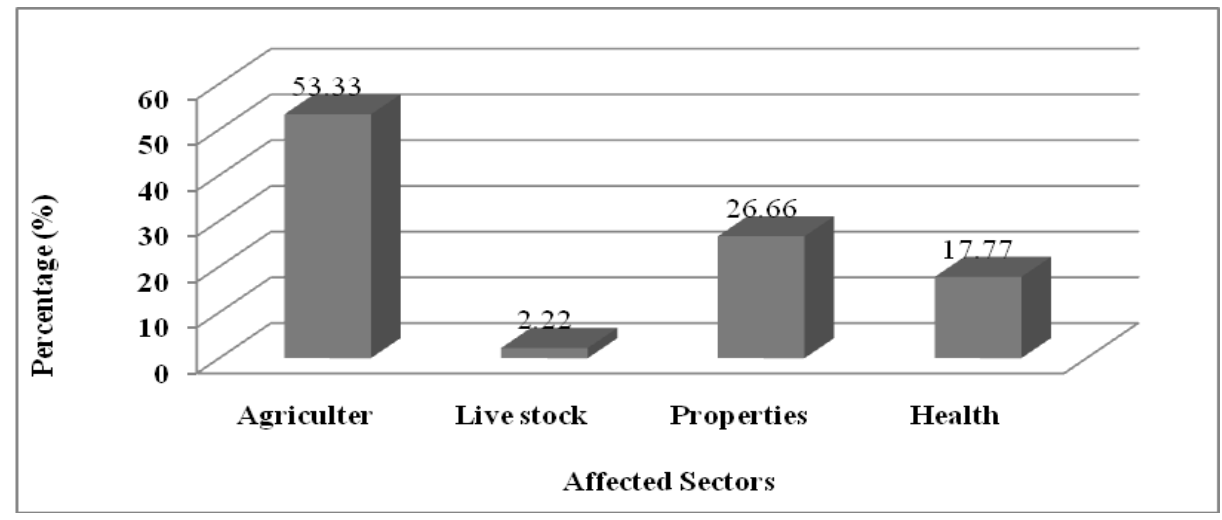

Fig. 3. Sectors Affected by Flood

\section{Diseases occur during/after flood}

Fig. 4. Shows that, Flood has many impacts on human being and environment. The person of the flood affected has seen suffered many contagious diseases like waterborne diseases such as typhoid, dysentery, cholera, hepatitis B, and diarrhea.
The study showed that, the $77.77 \%$ of respondent said that Diarrhea was the most common diseases during/after flood, followed by Typhoid and unpredicted diseases occur during/after flood in the study area.

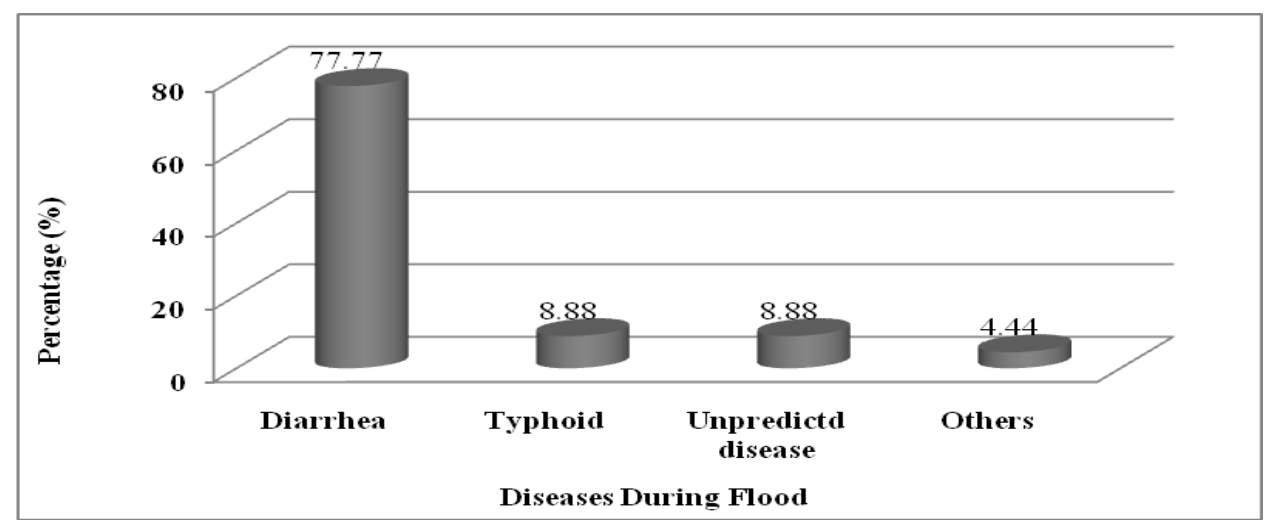

Fig. 4. Diseases occur during/after flood.

\section{Damage caused by flood}

The study revealed that, majority of the respondent said crop was damaged by the flood, the value was $57.77 \%$ followed by the $26.66 \%$ respondents who said that house was damaged by the flood. The percentages of respondent said the domestic animal and land were damaged by the flood and the values were $2.22 \%$ and $13.33 \%$ (Fig. 5.) respectively. 


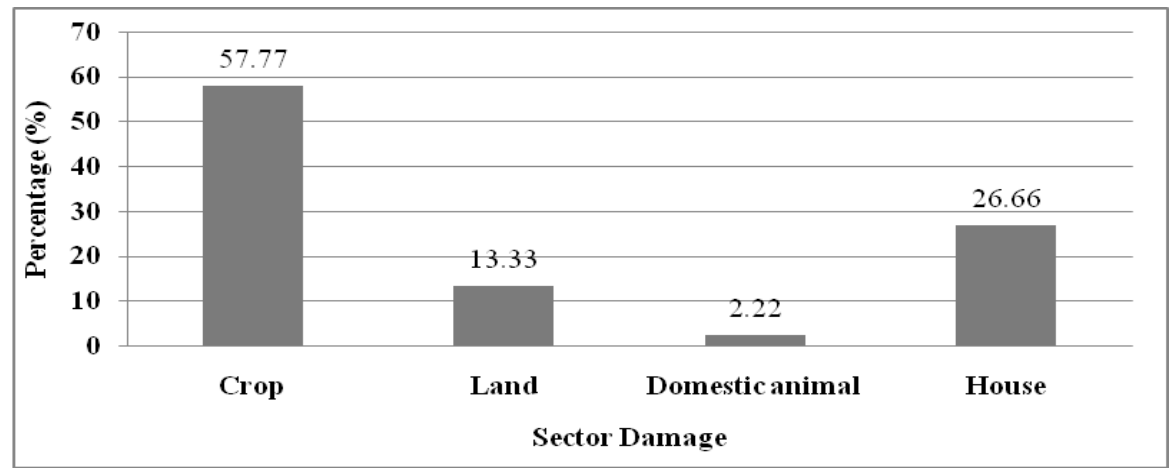

Fig.5. Damage caused by flood

Table 1. Type of Adaptation during flooding

\begin{tabular}{|c|c|}
\hline Type of Adaptation & Percentage (\%) \\
\hline Migration and storage food & 24.44 \\
\hline Vulnerable feeding and storage food & 68.88 \\
\hline Both & 6.66 \\
\hline
\end{tabular}

The Table 1 shows that, the percentage of the respondent take adaptation during flood of Vulnerable feeding and storage, the value was $68.88 \%$, which was the highest, followed by the $24.44 \%$ respondents who said they took have migration and stored food type of adaptation during flood. Only the $6.66 \%$ respondent said they take both type of adaptation during flood.

\section{Opinion to manage flood}

There are various methods of managing flood. The study revealed that, the $82.22 \%$ of respondent said that road construction and loan from bank is the most common managements system to manage flood, followed by the $11.11 \%$ of respondents who said the long term loan from bank and river dredging. The respondents said the dam making and planting trees were the management systems $6.66 \%$ (Fig. 6).

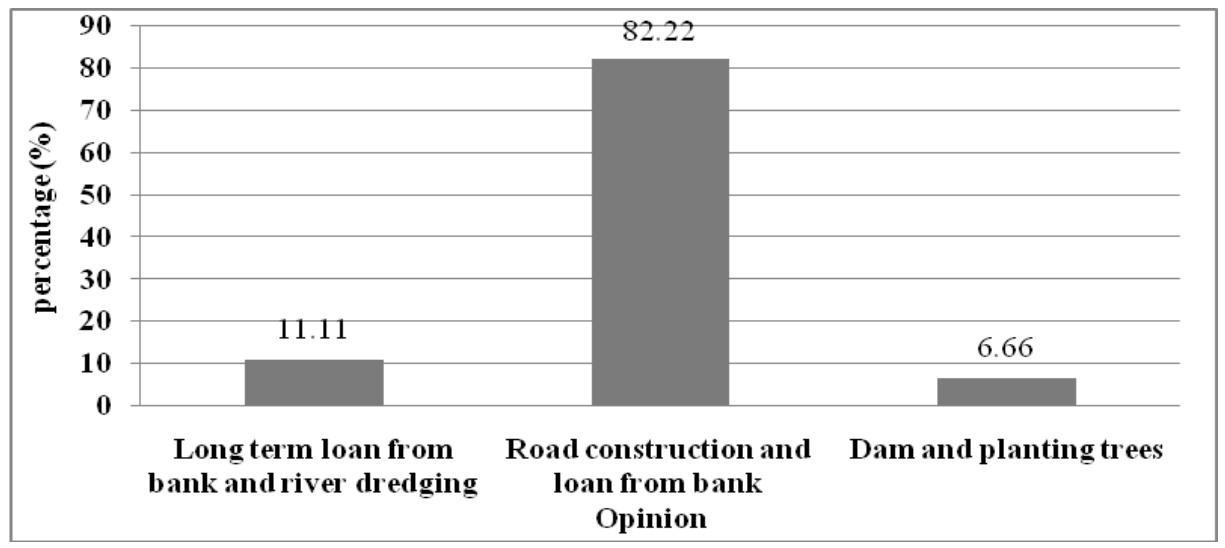

Fig. 6. Opinion to manage flood

\section{Conclusion}

Flooding is a natural phenomenon, which cannot be prevented. The flood control measures and policies should be directed to mitigation of flood damage, rather than flood prevention. Most of the people of Char land area are facing various problems such as sanitation and health, change of food habit; among them loss of permanent resident and becoming environmental refugees during flood. The result shows that, due to flood, most of the people lost their job and led to decrease income level. Normally the intensity of increases flood in July-August and people face severe problems for food, damage of crop and road infrastructure is among others. Various diseases like waterborne such cholera, dysentery, fever, diarrhea and some other diseases occur. Moreover, 
good governance, appropriate environmental laws, acts and ordinances will be necessary to achieve sustainable economic development and to reduce any environmental degradation. In addition, implementation of an improved real-time flood and drought control warning system can reduce damage caused by floods. A greater understanding of the processes that contribute to increased flooding susceptibility, however, can help us mitigate the adverse effects on human lives, environment, and economy.

\section{Reference}

Ahmad, M. 1989. Deluge in the delta. In: Ahmad, M. (Editor): Flood in Bangladesh, Community Development Library, Dhaka, pp. 3-40.

A. M. 2005. Assimilation and modeling of the atmospheric hydrological cycle in the ECMWF Forecasting system, Bull. Am. Met. Soc., pp. 86, 387-402.

Abrahams, M. J.; Price, J.; Whitlock, F. A. and Williams, G. 1974. The Brisbane floods, their impact on health, pp. 2:936- 939

Banglapedia, 2009. The National Encyclopedia of Bangladesh.

Brammer, H. 1990. Floods in Bangladesh: II. Flood Mitigation and Environmental Aspects. The Geographical Journal, 156(2): 65.

Bangladesh Bureau of Statistics (BBS), 2003. Bangladesh Population Census 2001, National Report (Provisional), Planning Division, Ministry of Planning, pp. 17, 30.
BWDB, 1975. Annual report on flood in Bangladesh. Flood Forecasting and Warning, Bangladesh Water Development Board, Dhaka, Flood publication No. 2, pp. 75, 95

Bangladesh facing the 21th century," State of the Environment", 2001.

Chowdhury, A. M. R. 1988. The 1987 flood in Bangladesh: an estimate of damage in twelve villages. Disasters, v. 12(4): 294-300.

Chowdhury E. H. 2004. Human adjustments to river bank erosion hazard in the Jamuna floodplain, Bangladesh, Human Ecology., vol 16.page no.4.

Dewan, M. L. 1989. Floods in Bangladesh: What are the solutions, International Society of Bangladesh, Concordia University Montreal Canada, pp. 56

Elahi, K. M.; Ahmed, K. S. and Mafizuddin, M. 2007. Bangladesh: An overview. Riverbank erosion, flood hazard and population displacement in Bangladesh. Dhaka, Riverbank Erosion Impact Study (REIS), pp. 364. Emily Wax in Flood-Prone Bangladesh, a Future That Floats, Washington Post Foreign Service. 